\title{
MENINGKATKAN HASIL BELAJAR IPA TENTANG CARA PERKEMBANGBIAKAN TUMBUHAN DENGAN KETERAMPILAN PROSES DI KELAS VI SDN SUMBERAGUNG 03 KECAMATAN PLUMPANG TUBAN PADA SEMESTER I TAHUN PELAJARAN 2015/2016
}

\author{
Siti Juma'iyah \\ SDN Sumberagung 03 Kecamatan Plumpang Tuban \\ e-mail:sitijumaiyah03@gmail.com
}

\begin{abstract}
Abstrak: Tujuan penelitian ini adalah untuk mendeskripsikan: (1) pendekatan pembelajaran keterampilan proses dapat meningkatkan hasil belajar IPA tentang Cara Perkembangbiakan Tumbuhan bagi siswa kelas VI SDN Sumberagung 03 Kecamatan Plumpang Tuban pada semester I tahun pelajaran 2015/2016. (2) peningkatan hasil belajar IPA tentang Cara Perkembangbiakan Tumbuhan melalui pembelajaran keterampilan proses bagi siswa kelas VI SDN Sumberagung 03 Kecamatan Plumpang Tuban pada semester I tahun pelajaran 2015/2016. Rancangan penelitian ini berbentuk penelitian tindakan kelas. Pelaksanaannya dalam penelitian ini terbagi menjadi dua siklus perencanaan, tindakan, observasi dan refleksi. Sebagai subjek penelitian adalah siswa kelas VI SDN Sumberagung 03 Kecamatan Plumpang Tuban tahun pelajaran 2015/2016 berjumlah 12 siswa, terdiri dari 7 siswa laki-laki dan perempuan sebanyak 5 siswa. Analisis data dilakukan secara deskriptif kualaitatif dengan menggunakan persentase dan rata-rata. Kesimpulan Hasil penelitian ini adalah: (1) dengan penerapan keterampilan proses dapat meningkatkan hasil belajar IPA tentang perkembangbiakan tumbuhan pada siswa kelas VI SDN Sumberagung 03 Kecamatan Plumpang Tuban pada semester I tahun pelajaran 2015/2016. (2) peningkatan hasil belajar IPA pada siswa kelas VI SDN Sumberagung 03 Kecamatan Plumpang Tuban pada pelaksanaan pembelajaran siklus I mencapai nilai rata-rata yaitu 68,33 dan pada siklus II nilai rata-rata hasil belajar siswa meningkat menjadi 76,67. Terjadi peningkatan nilai rata-rata hasil belajar dari siklus I ke siklus II sebesar 8,34 poin. Sedangkan mengenai ketuntasan belajar siswa secara klasikal pada siklus I mencapai $25 \%$, dan pada siklus II mencapai 92\%. Sehingga terjadi peningkatan ketuntasan belajar secara klasikal dari siklus I ke siklus II sebesar 67\%.
\end{abstract}

Kata kunci: hasil belajar, perkembangbiakan tumbuhan, keterampilan proses

Abstract: The research objective was to describe: (1) the learning process skills approach can improve learning outcomes IPA on How to Plant Breeding for students of VI grade SDN Sumberagung 03 Plumpang District Tuban in the first half year 2015/2016. (2) improvement of learning outcomes IPA on How to Plant Propagation through skills learning process for students of VI grade SDN Sumberagung 03 Plumpang District Tuban in the first semester of the school year 2015/2016. This study uses classroom action research design. Obviously in this study were divided into two cycles of planning, action, observation, and reflection. As research subjects are students of VI grade SDN Sumberagung 03 Plumpang District Tuban school year 2015/2016 amounted to 12 students, made up of boys as much as 7 children and women students as much as 5 children. Kualaitatif descriptive analysis of the data by using percentage and average. Conclusion The results of the study are: (1) The application of the approach in learning science process skills on "How to Plant Breeding" can improve student learning outcomes SDN Sumberagung 03 District Plumpang Tuban during the first semester of the school year 2015/2016. (2) With the approach of learning science process skills in VI grade student learning outcomes SDN Sumberagung 03 Plumpang District Tuban increased. The study results indicated an increase of the implementation of the first cycle of the average value of student learning outcomes reached 68.33 and the second cycle of the average value of student learning outcomes increased to 76.67. There was an increase in the average value of the learning 
outcomes of the first cycle to the second cycle of 8,34 points. Whereas in classical learning completeness students in the first cycle reaches $25 \%$, and the second cycle increased to $92 \%$. There is an increase in the classical mastery learning from the first cycle to the second cycle of $67 \%$.

Keywords: result study, plant breeding, skills learning process

\section{PENDAHULUAN}

Proses pembelajaran dapat dikatakan sebagai inti dari kegiatan yang dapat menjadi tolok ukur keberhasilan suatu upaya pendidikan. Ada beberapa unsur dalam suatu proses pembelajaran untuk mempermudah pencapaian tujuan dalam pembelajaran, yaitu: (1) merencanakan suatu kegiatan yang dilakukan guru sebelum melakukan suatu pembelajaran di dalam kelas, (2) interaksi dengan siswa, hal ini dilakukan untuk menciptakan suasana kondusif agar mencapai tujuan yang diinginkan, (3) evaluasi belajar siswa yaitu kegiatan akhir yang dilakukan oleh guru untuk memperoleh penilaian dalam bentuk formal, mengumpulkan informasi mengenai apa yang sudah dicapai siswa dan dipersiapkan secara khusus serta melakukan tindakan perbaikan apabila belum mencapai tujuan.

Dengan demikian tentang keberhasilan dalam pembelajaran kuncinya sangat ditentukan oleh kemampuan serta keterampilan guru dalam memilih pendekatan dan strategi pembelajaran serta pengelolaan dalam proses pembelajaran yang tepat untuk mencapai hasil pembelajaran yang optimal. Untuk itu dibutuhkan guru yang mempunyai kreativitas dan inovasi pembelajaran sesuai dengan dinamika perkembangan zaman dan guru senantiasa melakukan perbaikan dan peningkatan mutu dalam melaksanakan proses pembelajaran. Dengan adanya peningkatan mutu pada pembelajaran, maka muaranya adalah mutu pendidikan dapat meningkat.

Selain itu terdapat beberapa faktor yang menentukan keberhasilan suatu pembelajaran antara lain penguasaan bahan ajar, perhatian siswa pada bahan yang dipelajari dan keterlibatan siswa dalam pembelajaran serta strategi yang digunakan dalam pembelajaran.

Pembelajaran untuk mata pelajaran IPA saat ini model yang diterapkan oleh guru kelas VI adalah ekspositori. Model ekspositori merupakan kegiatan mengajar yang terpusat pada guru, dalam menyampaikan materi bahan ajar kepada siswa. guru menggunakan metode ceramah, sementara siswa hanya berperan sebagai pelacak dan pencari informasi melalui buku pelajaran dan menyelesaikan tugas yang diberikan guru sehubungan dengan penilaian guru.

Karena metode pembelajaran yang diterapkan metode yang di sukai oleh guru yaitu metode ceramah, maka pengaruhnya siswa cenderung terpaku pada teori yang ada dalam buku pegangan dan cenderung siswa mempelajari konsep-konsep yang ada dengan cara menghafal tanpa memperoleh pengalaman belajar secara langsung. Artinya siswa hanya memperoleh pengalaman secara verbal karena dari hasil belajar yang hanya sekadar menghafalnya.

IPA diperlukan dalam kehidupan seharihari untuk memenuhi kebutuhan manusia melalui pemecahan masalah-masalah yang dapat diidentifikasikan. Penerapan pembelajaran IPA perlu dilakukan secara bijaksana agar tidak berdampak buruk terhadap lingkungannya. Di tingkat SD diharapkan ada pemecahan pembelajaran IPA yang diarahkan pada pengalaman belajar siswa untuk merancang dan membuat suatu karya dan unjuk kerja melalui aplikasi konsep sains dan kompetensi belajar secara ilmiah. 
Pembelajaran IPA (sains) akan lebih baik apabila dilaksanakan secara ilmiah (scientific inquiry) untuk menumbuhkan kemampuan berpikir, bekerja, dan bersikap ilmiah serta mengomunikasikannya sebagai aspek penting kecakapan hidup. Oleh karena itu pembelajaran IPA di SD menekankan pada pemberian pengalaman belajar langsung melalui penggunaan dan pengembangan keterampilan proses dan sikap ilmiah” (Depdiknas, 2006:203).

Rendahnya penguasaan materi pelajaran IPA diduga karena guru kurang tepat dalam memilih pendekatan, strategi, dan metode pembelajaran. Rendahnya pemahaman siswa dalam pembelajaran ini berimbas pada hasil belajarnya. Pada saat belajar IPA diupayakan menanamkan dasar-dasar berpikir ilmiah pada diri siswa, sehingga dalam proses pembelajaran siswa lebih banyak belajar sendiri, mengembangkan kreativitas dalam memecahkan masalah. Siswa benarbenar ditempatkan sebagai subjek yang belajar sedangkan peranan guru dalam pembelajaran sebatas sebagai pembimbing dan fasilitator.

Banyak variasi yang dapat dikembangkan oleh guru dalam pembelajaran IPA. Salah satunya guru dapat mengembangkan pembelajaran dengan pendekatan keterampilan proses. Pendekatan keterampilan proses ini dipandang efektif dalam pembelajaran IPA (sains) karena keterampilan proses tidak hanya meningkatkan pemahaman siswa terhadap konsep-konsep dalam sains saja, melainkan juga membentuk sikap keilmiahan dalam diri siswa. Alasan rasional penggunaan keterampilan proses adalah siswa akan mendapatkan pemahaman yang lebih baik mengenai IPA dan akan lebih tertarik terhadap IPA jika mereka dilibatkan secara aktif. Investigasi dan inkuiri yang dilakukan oleh siswa merupakan tulang punggung pendekatan keterampilan proses. Investigasi ini difokuskan untuk memahami konsep-konsep IPA dan meningkatkan keteram- pilan proses berpikir ilmiah siswa. Menurut Blosser (dalam Subiyanto, 1990) bahwa "pemahaman konsep merupakan hasil dari proses berpikir ilmiah tersebut".

Fakta yang ditemukan dari hasil observasi dan pengalaman mengajar yang dilakukan guru bahwa siswa kelas VI SDN Sumberagung 03 Kecamatan Plumpang Tuban secara umum masih mengalami kesulitan dalam memahami materi pelajaran IPA yang diberikan guru. Dan ketika guru menyampaikan materi pelajaran banyak siswa tidak memperhatikan, dan mereka ada yang bermain-main sendiri, ada juga yang bukabuka buku lain. Kemudian terlihat juga, siswa yang berada di sudut belakang malah ada yang mengantuk, dan tiga siswa di sampingnya kurang bergairah untuk mengikuti pelajaran karena jenuh dan bosan sehingga menyebabkan hasil belajar IPA yang dicapai siswa rendah. Fakta tersebut terbukti hasil belajar yang dicapai siswa menunjukkan bahwa dari 12 siswa hanya 9 siswa $(33,6 \%)$ yang mampu mencapai hasil belajar (tuntas) sesuai dengan kriteria ketuntasan minimal 70 yang ditetapkan sekolah.

Faktor yang menyebabkan rendahnya hasil belajar siswa untuk mata pelajaran IPA di kelas VI adalah sebagai berikut. (1) Pada saat pelaksanaan pembelajaran guru sering menggunakan metode konvensional seperti biasanya yaitu ceramah, tanya jawab, dan pemberian tugas dan setelah itu diadakan evaluasi dan hasilnya kurang efektif. (2) Dalam melaksanakan proses pembelajaran guru mengandalkan sumber belajar dari buku teks pelajaran dan kreativitas guru dalam menggunakan media pembelajaran, alat peraga IPA, dan sumber belajar yang ada di lingkungan sekolah masih kurang. (3) Dalam proses pembelajaran IPA guru cenderung lebih dominan dan kurang melibatkan siswa dalam aktivitas belajar secara kreatif dan mandiri. (4) Minat 
dan motivasi belajar siswa terhadap mata pelajaran IPA masih rendah.

Berdasarkan latar belakang masalah di atas yang mengakibatkan kegagalan dalam proses pembelajaran IPA maka guru merasa ingin memperbaiki proses pembelajaran dengan cara memilih pendekatan pembelajaran IPA secara efektif dan efisien sehingga dapat membuat siswa lebih aktif, kreatif, senang, serta lebih mudah memahami materi IPA yang disampaikan dengan melaksanakan penelitian tindakan kelas yang berorientasi pada pemecahan masalah dan memfokuskan pembahasan judul penelitian yaitu "Meningkatkan Hasil Belajar IPA tentang Cara Perkembangbiakan Tumbuhan Dengan Keterampilan Proses di Kelas VI SDN Sumberagung 03 Kecamatan Plumpang Tuban Pada Semester I Tahun Pelajaran 2015/2016.”

Adapun rumusan permasalahan dapat dikemukakan dalam penelitian tindakan kelas ini adalah: (1) Bagaimanakah pelaksanaan pembelajaran IPA tentang Cara Perkembangbiakan Tumbuhan dengan keterampilan proses dapat meningkatkan hasil belajar siswa kelas VI SDN Sumberagung 03 Kecamatan Plumpang Tuban pada semester I tahun pelajaran 2015/2016? (2) Apakah pembelajaran IPA tentang Cara Perkembangbiakan Tumbuhan dengan keterampilan proses dapat meningkatkan hasil belajar siswa kelas VI SDN Sumberagung 03 Kecamatan Plumpang Tuban pada semester I tahun pelajaran 2015/2016?

Sedangkan tujuan dari penelitian tindakan kelas adalah sebagai berikiut. (1) Ingin mendeskripsikan pelaksanaan pembelajaran IPA tentang Cara Perkembangbiakan Tumbuhan dengan keterampilan proses dapat meningkatkan hasil belajar siswa kelas VI SDN Sumberagung 03 Kecamatan Plumpang Tuban pada semester I tahun pelajaran 2015/2016. (2) Ingin mengetahui peningkatan hasil belajar IPA tentang Cara Perkembangbiakan Tumbuhan melalui pembelajaran dengan keterampilan proses pada siswa Kelas VI SDN Sumberagung 03 Kecamatan Plumpang Tuban pada semester I tahun pelajaran 2015/2016.

\section{TINJAUAN PUSTAKA}

Keterampilan proses adalah keterampilan yang diperoleh dari latihan kemampuan-kemampuan mental, fisik, dan sosial yang mendasar sebagai penggerak kemampuan-kemampuan yang lebih tinggi (Depdiknas, 2006). Kemampuan-kemampuan mendasar yang telah dikembangkan dan telah terlatih lama-kelamaan akan menjadi suatu keterampilan, sedangkan pendekatan keterampilan proses adalah cara memandang anak didik sebagai manusia seutuhnya. Cara memandang ini dijabarkan dalam kegiatan belajar mengajar memperhatikan pengembangan pengetahuan, sikap, nilai, serta keterampilan. Ketiga unsur itu menyatu dalam satu individu dan terampil dalam bentuk kreativitas. Carin (dalam Samatowa, 2008:12) mendefinisikan keterampilan proses IPA untuk anak-anak meliputi: a) mengamati, b) mencoba memahami apa yang diamati, c) mempergunakan pengetahuan baru untuk meramalkan apa yang terjadi, d) menguji ramalan-ramalan di bawah kondisi-kondisi untuk melihat ramalan tersebut benar. Di dalam IPA tercakup juga coba-coba dan melakukan kesalahan, gagal dan mencoba lagi karena IPA tidak menyediakan semua jawaban untuk semua masalah yang kita ajukan. Untuk itu selain materi IPA harus dimodifikasi, keterampilan proses-keterampilan proses IPA yang akan dilatihkan juga harus disesuaikan dengan perkembangan anak.

Melalui keterampilan proses ilmiah (scientific process skill). IPA sebagai proses diperoleh 
melalui kegiatan ilmiah yang disebut metode ilmiah. Untuk itu, mata pelajaran IPA harus mengembangkan keterampilan proses ilmiah tersebut. Berbagai keterampilan proses mengembangkan kecakapan hidup (life skill), bahkan kecakapan yang dipakai seumur hidup (long life skill). Misalnya kecakapan observasi, kecakapan memecahkan masalah secara ilmiah, kecakapan berpikir logis, deduktif dan induktif dan sebagainya. Oleh karena itu, sistem penilaian hasil belajar IPA menurut Usman (2003) "harus mengurus kemampuan siswa dalam melaksanakan keterampilan proses ilmiah dan menggunakan metode ilmiah."

Tentang hasil belajar menurut Agustina (2008:25) dimaknai sebagai hasil yang dicapai oleh siswa baik pada ranah kognitif, afektif, dan psikomotorik setelah menempuh serangkaian proses evaluasi yang dapat dinyatakan dalam angka, simbol, maupun kalimat." Aspek kognitif berkaitan dengan pengetahuan dan informasi yang diperoleh siswa. Aspek afektif berkaitan dengan sikap penghargaan, perasaan dan emosi. Sedangkan aspek psikomotorik berkaitan dengan perilaku motorik atau kegiatan berkaitan dengan gerak yang melibatkan anggota badan. Hasan Sadly (dalam Agustina, 2008) juga mengemukakan pengertian "hasil belajar adalah perolehan yang dicapai oleh tenaga atau daya kerja seseorang dalam waktu tertentu". Selanjutnya Dimyati dan Mudjiono (2004) mendefinisikan "hasil belajar adalah tingkat penguasaan yang ingin dicapai oleh siswa dalam mengikuti pembelajaran”. Pendapat lain dari Pervical dan Ellington (dalam Agustina, 2008:25) menyatakan "hasil belajar adalah kapasitas terukur dari perubahan individu yang diinginkan berdasarkan ciri-ciri (sifat-sifat) atau variabel bawaannya melalui perlakukan atau pengajaran tertentu."

\section{METODE}

Penelitian ini dirancang dalam bentuk penelitian tindakan kelas (classroom action research). Menurut Bahrowi, dkk. (dalam Arwati, 2008:35) mengatakan bahwa penelitian tindakan kelas bertujuan untuk memperbaiki dan meningkatkan layanan professional guru dalam menangani proses pembelajaran, di mana tujuan ini dapat dicapai dengan melakukan beberapa tindakan alternatif dalam memecahkan berbagai persoalan pembelajaran di kelas.

Penelitian ini dilaksanakan dalam 2 (dua) siklus. Setiap siklus terdiri dari 4 tahap yaitu perencanaan tindakan (planning), pelaksanaan tindakan (action), pengamatan (observasi), dan refleksi. Adapun alur dan prosedur pelaksanaan penelitian tindakan kelas ini dapat dikemukakan dalam bentuk diagram berikut ini.

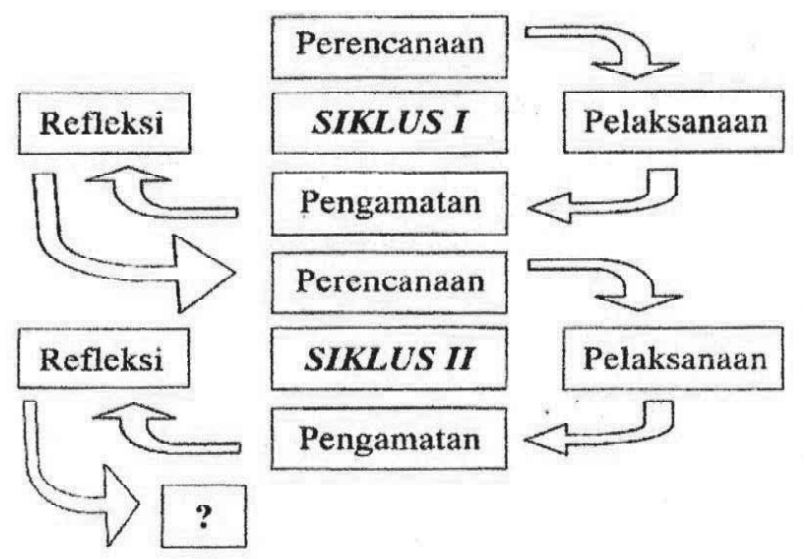

Gambar 1 Siklus Penelitian Tindakan Kelas (Arikunto, dkk., 2007:105)

Subjek dalam penelitian ini adalah siswa Kelas VI SDN Sumberagung 03 Kecamatan Plumpang Tuban sebanyak 12 siswa terdiri dari 7 siswa laki-laki dan 5 siswa perempuan. Tempat pelaksanaan penelitian tindakan kelas ini adalah di kelas VI SDN Sumberagung 03 Kecamatan Plumpang Tuban. Waktu pelaksanaan pada Semester I Tahun Pelajaran 2015/2016 dengan menerapkan dua siklus. Sebelum penelitian di- 
laksanakan diawali terlebih dahulu dengan kegiatan awal (pra-tindakan). Adapun waktu penelitian tindakan kelas untuk siklus I dilaksanakan dua kali pertemuan yaitu pada hari Kamis tanggal 3 September 2015, dan Sabtu tanggal 5 September 2015, sedangkan penelitian siklus II dilaksanakan dua kali pertemuan yaitu pada hari Kamis tanggal 10 September 2015 dan hari Sabtu tanggal 12 September 2015.

Teknik yang digunakan oleh peneliti untuk pengumpulan data adalah: (1) Observasi dilakukan oleh peneliti selama pelaksanaan proses pembelajaran berlangsung. Observasi digunakan peneliti untuk mengamati fenomena-fenomena yang terjadi di kelas dan untuk mengumpulkan data berkenaan dengan aktivitas guru dan siswa dalam melaksanakan proses pembelajaran. Adapun instrumen yang digunakan berupa pedoman observasi. (2) Tes, merupakan seperangkat soal yang akan digunakan untuk memperoleh data penelitian terutama berkaitan dengan hasil belajar siswa khususnya untuk mata pelajaran IPA. (3) Dokumentasi, merupakan bukti-bukti (benda) tertulis yang digunakan untuk mendapatkan data penelitian. Adapun bentuk dokumen yang dimaksud dalam penelitian ini meliputi RPP, bukti hasil pengamatan, bukti hasil pekerjaan siswa dan nilai tes, dan foto-foto hasil kegiatan penelitian.

Analisis data penelitian ini menggunakan deskriptif kualitatif. Adapun data-data hasil penelitian berupa keaktifan siswa yang dianalisis dengan rumus persentase (\%), dengan kategori nilai 86\%-100\% (Aktif); 65\%-85\% (Cukup aktif); dan $\leq 64 \%$ (Kurang aktif), sedangkan kemampuan siswa dalam menerapkan keterampilan proses dan hasil belajar IPA dianalisis dengan mencari nilai rata-rata dengan menggunakan kategori nilai 86-100 (Baik); 65-85 (Cukup baik); dan $\leq 64$ (Kurang baik). Selanjutnya untuk ketuntasan belajar secara individual siswa mencapai nilai $\geq 70$, sedangkan ketuntasan belajar klasikal ditetapkan 80\% dari jumlah seluruh siswa dalam kelas telah tuntas belajar (mencapai nilai $\geq 70$ ).

\section{HASIL PENELITIAN}

\section{Pra-Tindakan}

Pada kegiatan pra-tindakan berdasarkan fakta dan pengalaman guru dalam melaksanakan proses pembelajaran IPA di kelas VI SDN Sumberagung 03 Kecamatan Plumpang Tuban antara lain menggunakan metode pembelajaran secara konvensional (ceramah, tanya jawab, dan pemberian tugas). Dari penerapan model pembelajaran tersebut siswa hanya mempelajari konsep-konsep yang ada dalam buku saja kemudian disuruh menghafal tanpa memperoleh pengalaman langsung dan terlibat dalam proses pembelajaran. Akibatnya siswa kurang memperhatikan pada saat guru menyampaikan materi, merasa tidak bergairah dalam mengikuti pelajaran dan mereka lebih suka bermain dengan teman sebangkunya. Selain itu, motivasi dan aktivitas belajar siswa rendah (75\%) sehingga mengakibatkan hasil belajar mata pelajaran IPA pada saat ulangan formatif menunjukkan nilai rendah di bawah standar ketuntasan minimal yang ditetapkan sekolah. Berdasarkan pelaksanaan kegiatan pra-tindakan dilihat dari hasil pengamatan tentang kemampuan siswa dalam belajar IPA menunjukkan ratarata 65,00 (cukup baik), sedangkan hasil belajar IPA yang dicapai siswa menunjukkan nilai ratarata yaitu 58,75. Dari 12 siswa hanya terdapat 3 siswa (25\%) yang telah berhasil mencapai nilai 70 (tuntas belajar) atau sesuai dengan kriteria ketuntasan minimal (KKM) yang ditetapkan sekolah. 


\section{Siklus I}

Hasil penelitian siklus I dikemukakan antara lain: (1) dari pengamatan terhadap keaktifan siswa dalam proses pembelajaran dari 12 siswa Kelas VI SDN Sumberagung 03 Kecamatan Plumpang Tuban menunjukkan data yaitu siswa yang termasuk dalam kategori aktif belajar sebanyak 3 siswa (25\%), cukup aktif sebanyak 6 (50\%), dan sebanyak 3 siswa (25\%) menunjukkan kurang aktif. Dengan demikian dari hasil pengamatan terhadap keaktifan siswa kelas VI dalam belajar IPA dengan menerapkan pendekatan keterampilan proses secara umum menunjukkan cukup aktif dengan rata-rata 75,00\%. (2) Hasil dari penilaian kemampuan siswa dalam proses pembelajaran dengan menerapkan keterampilan proses dari 12 siswa menunjukkan data yaitu kemampuan siswa menunjukkan kategori baik sebanyak 2 siswa (16\%), cukup baik sebanyak 5 siswa (42\%), dan sebanyak 5 siswa (42\%) menunjukkan kemampuan kurang baik. Rata-rata kemampuan siswa menunjukkan 68,00 (cukup baik). (3) Hasil belajar siswa menunjukkan nilai rata-rata adalah 68,33 . Selanjutnya, mengenai ketuntasan belajar menunjukkan bahwa siswa yang dinyatakan tuntas belajar sebanyak 7 anak (58\%) dan siswa yang belum tuntas belajar sebanyak 5 anak (42\%). Sedangkan secara klasikal pada pelaksanaan pembelajaran IPA dengan menerapkan pendekatan keterampilan proses pada siklus I ketuntasan belajar secara klasikal mencapai 58\%, berarti dalam pembelajaran siklus I ini dapat dikatakan belum berhasil karena masih di bawah kriteria ketuntasan belajar yang ditetapkan sebesar $80 \%$.

\section{Siklus II}

Hasil penelitian siklus II dikemukakan yaitu:

(1) Dari pengamatan keaktifan siswa dalam proses pembelajaran dari 12 siswa kelas VI SDN Sumberagung 03 Kecamatan Plumpang Tuban menunjukkan data yaitu siswa yang termasuk dalam kategori aktif sebanyak 8 siswa (67\%), sedangkan sebanyak 4 siswa (33\%) menunjukkan dalam kategori cukup aktif. Dari hasil pengamatan terhadap keaktifan siswa kelas VI dalam belajar IPA dengan menerapkan pendekatan keterampilan proses secara umum menunjukkan aktif dengan rata-rata 91,67. (2) Dari pengamatan terhadap kemampuan siswa dalam belajar IPA dengan keterampilan proses menunjukkan kategori baik sebanyak 7 siswa (58\%), kategori cukup baik dalam belajar IPA dengan keterampilan proses sebanyak 5 siswa (42\%). Rata-rata kemampuan siswa dalam belajar IPA pada siklus II menunjukkan 85,58 (baik). (3) Dari penilaian hasil belajar IPA menunjukkan bahwa nilai rata-rata hasil belajar siswa adalah 76,67 .

Selanjutnya, mengenai ketuntasan belajar menunjukkan bahwa siswa yang dinyatakan telah tuntas belajar sebanyak 11 anak (92\%) dan siswa yang belum tuntas belajar sebanyak 1 anak (8\%). Sedangkan ketuntasan secara klasikal pada pelaksanaan pembelajaran IPA dengan menerapkan pendekatan keterampilan proses pada siklus II mencapai 92\% di atas kriteria ketuntasan belajar yang ditetapkan sebesar $85 \%$. Dengan demikian setelah dilakukan pembelajaran IPA dengan pendekatan keterampilan proses maka hasil belajar IPA yang dicapai siswa kelas VI SDN Sumberagung 03 Kecamatan Plumpang Tuban menunjukkan peningkatan.

Berdasarkan hasil proses pembelajaran sejak dilakukan kegiatan pra-tindakan sampai pada kegiatan penelitian tindakan kelas tentang pembelajaran IPA dengan menerapkan pendekatan keterampilan proses yang dilaksanakan pada siklus I dan siklus II mengalami peningkatan 
baik kemampuan siswa dalam belajar maupun hasil belajar IPA bagi siswa kelas VI SDN Sumberagung 03 Kecamatan Plumpang Tuban maupun ketuntasan belajar sesuai dengan KKM yang ditetapkan oleh sekolah. Peningkatan tersebut secara lebih jelas dapat dilihat pada tabel di bawah ini.

Tabel 1 Rangkuman Hasil Kegiatan Penelitian Tindakan Kelas

\begin{tabular}{|l|c|c|c|c|}
\hline \multirow{2}{*}{$\begin{array}{c}\text { Kegiatan } \\
\text { Penelitian }\end{array}$} & \multicolumn{2}{|c|}{ Nilai Rata-rata } & \multicolumn{2}{|c|}{$\begin{array}{c}\text { Ketuntasan } \\
\text { Belajar } \\
\text { Klasikal (\%) }\end{array}$} \\
\cline { 2 - 5 } & Kmp & HB & T & TT \\
\hline $\begin{array}{l}\text { Pra- } \\
\text { Tindakan }\end{array}$ & 65,00 & 58,75 & $25 \%$ & $75 \%$ \\
\hline Siklus I & 68,00 & 68,33 & $58 \%$ & $42 \%$ \\
\hline Siklus II & 85,58 & 76,67 & $92 \%$ & $8 \%$ \\
\hline
\end{tabular}

Berdasarkan tabel tersebut dapat diilustrasikan pada grafik sebagai berikut.

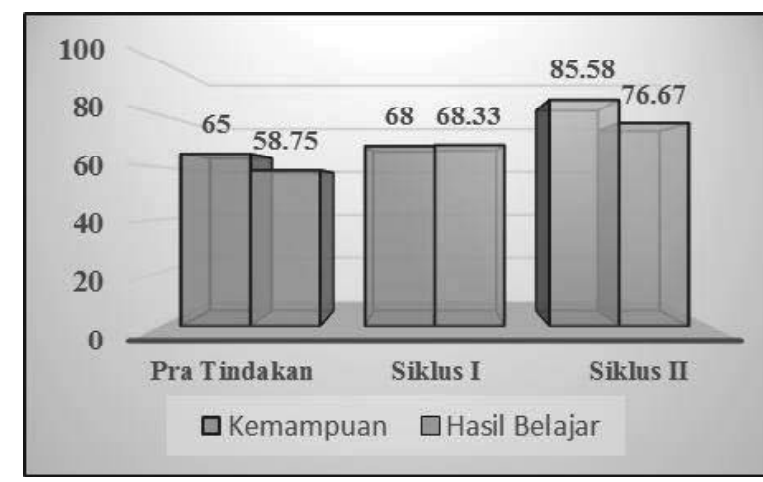

Grafik 1 Peningkatan Kemampuan Siswa dan Hasil Belajar IPA

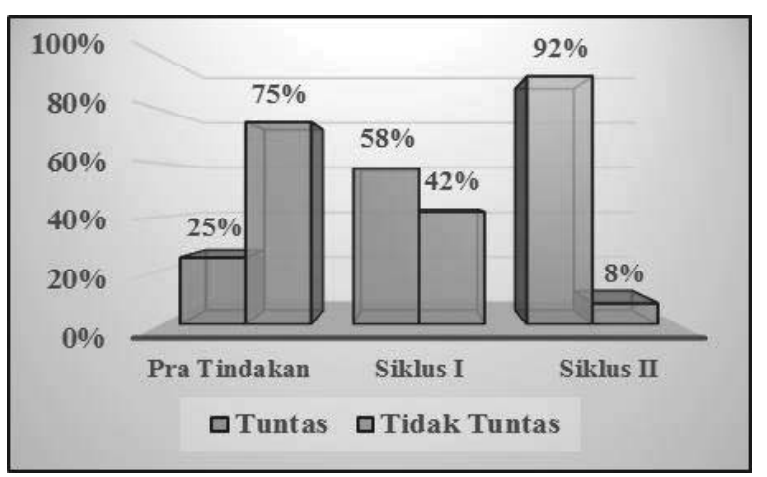

Grafik 2 Peningkatan Ketuntasan Belajar IPA Secara Klasikal

\section{SIMPULAN DAN SARAN}

Berdasarkan hasil penelitian dan pembahasan di atas dapat ditarik kesimpulan sebagai berikut: (1) Penerapan keterampilan proses dalam pembelajaran IPA tentang "cara perkembangbiakan tumbuhan" dapat meningkatkan hasil belajar siswa kelas VI SDN Sumberagung 03 Kecamatan Plumpang Tuban pada Semester I tahun pelajaran 2015/2016. (2) Peningkatan hasil belajar IPA kelas VI SDN Sumberagung 03 Kecamatan Plumpang ditunjukkan dari hasil kegiatan pra-tindakan mencapai nilai rata-rata hasil belajar siswa mencapai 58.75. Selanjutnya dari pelaksanaan siklus I mencapai nilai ratarata 68,33, dan pada siklus II nilai rata-rata hasil belajar siswa meningkat menjadi 76,67. Ada peningkatan nilai rata-rata hasil belajar dari siklus I ke siklus II sebesar 8,34 poin. Sedangkan mengenai ketuntasan belajar siswa secara klasikal dari kegiatan pra-tindakan mencapai 25\%, pada siklus I mencapai 58\%, dan pada siklus II meningkat 92\%. Ada peningkatan ketuntasan belajar secara klasikal dari siklus I ke siklus II sebesar 67\%.

Dari kesimpulan hasil penelitian tersebut di atas, maka peneliti mengemukakan saran sebagai berikut. (1) Dalam upaya peningkatan kualitas pembelajaran khususnya IPA hendaknya guru kelas menerapkan strategi dan pendekatan pembelajaran lebih variatif dan inovatif. (2) Agar aktivitas belajar, motivasi, dan keterampilan berpikir kritis siswa berkembang sehingga hasil belajar siswa untuk mata pelajaran IPA meningkat, hendaknya guru dalam proses pembelajaran menerapkan pendekatan keterampilan proses. (3) Agar pihak sekolah memfasilitasi dan melengkapi alat peraga, media pembelajaran, dan laboratorium IPA untuk meningkatkan kompetensi dan profesionalitas guru dalam pelaksanaan pro- 
ses pembelajaran IPA sehingga prestasi belajar siswa dapat tercapai maksimal.

\section{DAFTAR PUSTAKA}

Agustina, Dora Tri. 2008. Penerapan Pendekatan PAKEM dalam Pembelajaran IPA untuk Meningkatkan Hasil Belajar Siswa Kelas VI SDN Ngiliran I Magetan. Malang: Universitas Negeri Malang.

Akbar, Sa'dun. 2008. Penelitian Tindakan Kelas Filosofi, Metodologi, dan Implementasinya. Malang: Surya Pena Gemilang.

Arikunto, Suharsimi. 2007. Prosedur Penelitian Suatu Pendekatan Praktik. Jakarta: Rineka Cipta.
Arwati. 2005. Implementasi Pendekatan Keterampilan Proses dalam Pembelajaran IPA pada Pokok Bahasan Penyakit. Malang: Universitas Negeri Malang.

Depdikbud. 2014. Penelitian Tindakan Kelas. Jakarta: Depdikbud.

Depdiknas. 2006. Standar Kompetensi dan Kompetensi Dasar Tingkat SD (KTSP). Jakarta: Depdiknas.

Samatowa, Usman. 2008. Bagaimana Membelajarkan IPA di Sekolah Dasar. Jakarta: Depdiknas.

Usman, Uzer. 2003. Upaya Optimalisasi Kegiatan Pembelajaran. Bandung: Remaja Rosda Karya. 
Education and Human Development Journal, Vol. 3, No. 1, April 2018 


\section{PETUNJUK PENULISAN NASKAH}

1. Education and Human Development Journal berisi artikel tentang kajian teori dan hasil penelitian di bidang pendidikan.

2. Artikel dikirim belum pernah dimuat di media cetak lain, ditulis dalam bahasa Indonesia/Inggris dan diketik dengan program Microsoft Word dengan font 12, menggunakan huruf Times New Roman spasi 1,5, pada kertas A4 sepanjang 15-20 halaman, dikirim ke email: ehdj@unusa.ac.id

3. Identitas penulis artikel ditulis tanpa gelar akademik ditempatkan di bawah judul artikel disertai nama dan alamat institusi, alamat e-mail dan telepon/HP, untuk memudahkan komunikasi. Jika penulis terdiri dari empat orang atau lebih, yang dicantumkan di dalam judul adalah nama penulis utama, sedangkan nama penulis lainnya dicantumkan sebagai catatan kaki pada halaman pertama.

4. Artikel hasil penelitian memuat:

Judul

- Nama Penulis (tanpa gelar akademik)

- Abstrak (75-100 kata) dalam bahasa Indonesia dan Inggris dengan program Microsoft Word dengan font 12, menggunakan huruf Times New Roman spasi 1, pada kertas A4.

- Kata-kata kunci (maksimal 5 kata)

- Pendahuluan (tanpa subjudul) memuat latar belakang masalah, perumusan masalah, rangkuman kajian teoretis, dan tujuan penelitian

- Tinjauan pustaka (memuat sedikit teori yang mendasari tulisan)

- Metode

- Hasil dan pembahasan (dapat dibagi beberapa sub bagian)

- Simpulan dan saran

- Daftar pustaka (rujukan minimal 70\% terbitan 10 tahun terakhir dan hanya memuat sumber-sumber yang di rujuk saja)

5. Artikel kajian teoretis (non-penelitian) memuat:

- Judul

- Nama Penulis

- Abstrak (75-100 kata) dalam bahasa Indonesia dan Inggris

- Kata-kata kunci

- Pendahuluan (tanpa subjudul) memuat pengantar topik utama diakhiri dengan rumusan tentang hal-hal pokok yang akan dibahas.

- Subjudul

- Subjudul

- Subjudul

- Penutup

- Daftar pustaka

6. Sumber rujukan diharapkan dari sumber primer, seperti laporan penelitian (skripsi, tesis, disertasi) atau artikel hasil penelitian yang dimuat dalam jurnal berkala ilmiah, dan ditulis secara alfabetis.

7. Penulis diwajibkan menyumbang biaya penerbitan dengan besaran yang layak.

8. Daftar rujukan ditulis dengan tata cara seperti contoh berikut ini dan diurutkan secara alfabetis dan kronologis.

Buku:

Anderson, D.W., Vault, V.D. \& Dickson, C.E. 1999. Problem and Prospects for the Decades Ahead: Competency Based Teacher Education. Berkeley: McCutchan Publishing Co.

Buku kumpulan artikel:

Saukah, A. \& Waseso, M.G. (Eds.).2002. Menulis artikel untuk jurnal ilmiah. (Edisi ke-4, cetakan ke-1). Malang: UM Press.

Artikel dalam buku kumpulan artikel:

Russel, T. 1998. An alternative Conception: Representing Representation. Dalam P.J. Black \& A. Lucas (Eds.), Children's Informal Ideas in Science (hlm.62-84). London: Routledge. 
Artikel dalam jurnal atau majalah:

Kansil, C. L. 2002. Orientasi Baru Penyelenggaraan Pendidikan Program Profesional dalam Memenuhi Kebutuhan Dunia Industri. Transpor, XX (4):57-61

Artikel dalam koran:

Pitunov, B.13 Desember, 2002. Sekolah Unggulan ataukah Sekolah Pengunggulan? Majapahit Pos, hlm. 4\&11.

Tulisan/berita dalam koran (tanpa nama pengarang):

Jawa Pos. 22 April, 1995. Wanita Kelas Bawah Lebih Mandiri, hlm.3.

Dokumen resmi:

Pusat Pembinaan dan Pengembangan Bahasa. 1978. Pedoman Penulisan Laporan Penelitian. Jakarta: Depdikbud. Undang-undang Republik Indonesia Nomor 20 Tahun 2003 tentang Sistem Pendidikan Nasional.2004. Malang: Angkasa.

Buku terjemahan:

Ary, D., Jacobs, L.C. \& Razavieh, A. 1976. Pengantar Penelitian Pendidikan. Terjemahan oleh Arief Furchan. 1982. Surabaya: Usaha Nasional.

Skripsi, Tesis, Disertasi, Laporan Penelitian:

Makmara. Thontjie.2009. Tuturan Persuasif Wiraniaga dalam Berbahasa Indonesia: Kajian Etnografi Komunikasi. Disertasi tidak diterbitkan. Malang: Pascasarjana Universitas Negeri Malang.

Makalah seminar, lokakarya, penataran:

Waseso, M.G. 2001. Isi dan Format Jurnal Ilmiah. Makalah disajikan dalam Seminar Lokakarya Penulisan Artikel dan Pengelolaan Jurnal Ilmiah, Universitas Lambungkurat, Banjarmasin, 9-11 Agustus.

Internet (Karya Individual):

Hitchcock, S., Carr, L. \& Hall, W. 1996. A Survey of STM Online Journals, 1990-1995: The Calm before the Storm, (Online), (http://journal.ecs.soton.ac.uk/survey/survey.html, diakses 12 Juni 1996).

Internet (artikel dalam jurnal online):

Widiati, Utami. 2008. Pembelajaran Membaca-Menulis melalui Buddy Journals untuk Meningkatkan Kemampuan Menulis Mahasiswa Jurusan Sastra Inggris. Jurnal Bahasa dan Seni. (Online), Tahun 36, Nomor 2, Agustus 2008 (http://sastra.um.ac.id, diakses 3 Februari 2010).

Internet (bahan diskusi):

Wilson, D. 20 November 1995. Summary of Citing Internet Sites. NETRAIN Discussion List, (Online), NETRAIN@ubvm.cc.buffalo.edu, diakses 22 November 1995).

Internet (e-mail pribadi):

Naga, D.S. (ikip-jkt@indo.net.id). 1 Oktober 1997. Artikel untuk JIP. E-mail kepada Ali Saukah (jippsi@mlg. ywcn.or.id).

9. Tata cara penyajian kutipan, rujukan, tabel, dan gambar mengikuti ketentuan dalam Pedoman Penulisan Karya Ilmiah Universitas Nahdlatul Ulama Surabaya, atau mencontoh langsung tata cara yang digunakan dalam artikel yang dimuat. Artikel berbahasa Indonesia menggunakan Pedoman Umum Ejaan Bahasa Indonesia yang disempurnakan (Depdikbud, 1987). Artikel berbahasa Inggris menggunakan ragam baku.

10. Semua naskah ditelaah secara anonim oleh mitra bestari (reviewers) yang ditunjuk oleh penyunting menurut bidang kepakarannya. Penulis artikel diberi kesempatan untuk melakukan perbaikan (revisi) naskah atas dasar rekomendasi atau saran dari mitra bestari atau penyunting. Kepastian pemuatan atau penolakan naskah akan diberitahukan secara tertulis. 